Civic Review, Vol. 16, Special Issue, 2020, 434-444, DOI: 10.24307/psz.2020.1228

Péter Karácsony

\title{
Effects of the Coronavirus Crisis on Hungarian Small and Medium- Sized Enterprises
}

\section{SUMmary}

Today's coronavirus crisis has affected not only public health but also the economy. The coronavirus has led to a significant increase in unemployment and a transformation in employment. Each government tries to save its own economy in different ways, primarily by launching programmes that help companies maintain employment. The crisis has also generated spill-over effects throughout the supply chain. Available studies on the economic effects of the coronavirus are currently limited. Based on empirical research, this study endeavours to show the impacts of the coronavirus on the Hungarian economy. Based on the findings, it can be said that as a result of the coronavirus, Hungarian small and medium-sized enterprises are struggling hard to overcome financial difficulties and declining demand for services/products, and consequently government subsidies and measures are vital for them.

Journal of Economic Literature (JEL) codes: E60, F23, M21, O11
Keywords: COVID-19, Hungary, economic effects, government measures, crisis

\section{INTRODUCTION}

Today, our world is in awe of a dangerous virus, the so-called coronavirus (COVID-19), which has claimed a great number of human lives since its spread in late 2019. Initially, it raged in Asia and then gradually spread throughout the world. It is now certain that the virus is not only a threat to human life but is also increasingly threatening the world economy.

COVID-19 is a viral respiratory disease caused by a coronavirus. Currently, 7 coronaviruses are known to infect humans, including SARS and MERS (Ahmad and Hui, 2020). Today's coronavirus pandemic is caused by the SARS-CoV-2 virus, a disease called COVID-19 for short. The first cases were discovered in December 2019 in Wuhan Province, China. As with the SARS pandemic in 2002-2003, the economic effects appeared shortly after the disclosure of the

Péter KarÁcsony PhD, associate professor, ELTE Eötvös Loránd University, Institute of Research on Adult Education and Knowledge Management, Budapest (karacsony.peter@ppk.elte.hu). 


\section{Academic Workshop}

first identified cases (Liu et al., 2020). The outbreak was declared a pandemic by the World Health Organisation (WHO) on 11 March 2020 (Shah and Farrow, 2020). In order to stop the spread of the pandemic and prevent its devastating effects, governments and large corporations have made drastic decisions (Inozemtsev, 2020). Some factories and businesses switched to survival mode to avoid mass layoffs, so they were forced to either reduce production or reschedule working hours (Martirosyan, 2020).

During the first wave the governments of the world realised that mass illness could not be avoided, and so they made efforts at containing the pandemic (Manjula Bai, 2020). The pandemic hit Hungary on March 4, 2020. In order to slow the spread of the virus, restrictions are in place throughout Hungary, of which the following are most perceptible for citizens:

- Social distancing (In public places people must keep a distance of at least 1.5 meters),

- Limited access to services,

- Mandatory covering of the mouth and nose in public places.

In addition to the restrictions affecting the internal market, a number of international regulations affecting cross-border movement have also been introduced. Special mention should be made of the 1 September 2020 ban on entry to the territory of Hungary by foreign citizens, with the exception specified by law. The primary purpose of this measure was to prevent the introduction of the virus from abroad. The most important first economic protection measures affecting Hungarian enterprises were announced by Prime Minister Viktor Orbán on March 18, 2020. The most important of these measures included the sus- pension of the repayment of principal and the payment of interest on loans by private persons and businesses until the end of the year and the provision of government support to enterprises to facilitate the retention of employees.

Based on the international literature (Lund et al., 2020, Hite and McDonald, 2020), the coronavirus has had the most significant economic impact on jobs: numerous jobs have been lost and a great number of people have lost their jobs. It may be stated that the coronavirus will also have a significant impact on the Hungarian economy and society. Small and medium-sized enterprises (SMEs) play a significant role in the Hungarian economy, as more than two-thirds of the employees are employed by SMEs, and their production represents more than half of the national economy. Due to their flexibility and responsiveness, SMEs have an important potential for economic growth (Devins and Kimbara, 1997). According to the Hungarian Central Statistical Office, before the coronavirus crisis, there were more than 700,000 SMEs in Hungary, employing nearly 2 million people and contributing 53 per cent to GDP. The majority (almost $80 \%$ ) of SMEs were service providers, mainly engaged in retail trade, tourism, hospitality, vehicle repair, and scientific or technical activities.

The aim of the study is to examine the impacts of the coronavirus on Hungarian SMEs.

\section{LITERATURE REVIEW}

In recent decades, the global business environment has been characterised by unpredictability and uncertainty. In the recent decades the most significant event that has affected and dramatically changed the 


\section{Academic Workshop}

global business environment was the 20072008 global crisis. During the 2008 global financial crisis, which originated from the United States, several large companies went bankrupt or were forced to merge with their competitors (Foo and Witkows$\mathrm{ka}, 2017)$. The coronavirus crisis is new in modern history, and we have never seen a similar health crisis affecting the economy to such an extent.

Every global economic crisis severely hits SMEs, which are important elements of national economies around the world (Gherghina et al., 2020). The OECD predicts that SMEs are the most exposed to the current coronavirus pandemic among the participants of the world economy. According to its experts, there is a danger that restrictions on free movement will be reconsidered in an increasing number of countries, and this may lead to a decline in production and in consumer confidence. Fernandes (2020) made an attempt at the quantification of the economic consequences of the coronavirus crisis, using the 1918-1919 flu pandemic as a basis of comparison. A global crisis like the one in 1918 will cost the economy USD 3 trillion, so the impact of coronavirus on the world economy can be expected to be around the same amount.

The COVID-19 pandemic is causing unprecedented devastation in global supply chains, which relies primarily on Chinese manufacturing performance and raw materials (Barua, 2020). There are two main channels for the effects of the global supply chain: one is production shocks and the other is shocks to trade flows, caused by transportation and logistics problems. Manufacturing shocks are large worldwide, with China accounting for 60 per cent of the global demand and supply and 41 per cent of the global manufacturing exports (Baldwin and Di Mauro, 2020).

In times of crisis, as a first step, organisations reduce their costs as an effective crisis management tool. In the developed parts of the world, the most expensive cost is labour. Therefore, the first step in dealing with the crisis is usually to review the number of employees, reduce working hours, and temporarily suspend the hiring of new employees (Vasa and Mendelényi, 2010; Lindley, 2020). The workforce available for companies is reduced because workers are ill or have to take care of their relatives (children and elderly relatives) and thus stay at home in times of crisis. Furthermore, the dramatic and sudden decline in the income of SMEs has a serious impact on their ability to operate and/or causes severe liquidity problems. In addition, the income situation of consumers deteriorates, which reduces their daily consumption through fear of infection and increased insecurity. This can also cause a decline in the main consumer segments of SMEs, which can then culminate in financial problems (Lentner et al., 2020). In light of the above considerations, SMEs are likely to be more vulnerable to "social distancing" than multinationals enterprises.

Another problem is that SMEs are in a tight financial situation, have hardly any financial reserves, and have very limited access to external financial resources (e.g. bank loans). In times of crisis, banks are even less willing to lend to SMEs, thus further increasing the pressure on these companies (Vasa, 2010; Táu and Cretoiu, 2014).

The survival of SMEs is extremely important for countries, as they account for 99 per cent of the registered businesses in Europe, employing around 66 million people. OECD, in collaboration with Facebook and 


\section{Academic Workshop}

the World Bank, produced two reports on the situation of SMEs, based on a questionnaire answered by tens of thousands of respondents. According to the report, 26 per cent of small businesses have disappeared due to the pandemic. Two-thirds of those surveyed reported a decline in income, and the remaining one-third was forced to reduce their headcount. Only a few per cent of the espondents (23\%) received financial support. Businesses want additional wage subsidies, tax cuts, and soft loans in order to manage their spending and falling demand (Facebook/OECD/World Bank, 2020).

\section{Methodology}

The aim of the research was to assess the impact of the COVID-19 crisis on the economy through the example of SMEs in Hungary. A structured questionnaire survey was used for collecting data. Two criteria were set up for participating in the survey: the business was required to have been operating continuously for at least 5 years, and to carry out its activities in the Western Transdanubia Region. This region was chosen because currently it is the third most developed region in Hungary after Budapest and the Central Transdanubia Region. According to the data of the Central Statistical Office, the gross domestic product per capita in the Western Transdanubia Region is 101.3 per cent of the national average. Győr-Moson-Sopron County, where a significant part of the respondents $(61 \%)$ are located, has even better results: gross domestic product per capita is 121.8 per cent of the national average, which is the second best indicator after Budapest (KSH, 2020a). In 2019, the number of economic organisations registered in the Western Transdanubia Region was 189,764; of which more than
90 per cent were classified as SMEs (KSH, 2020b). Respondents were selected by convenience sampling, using databases from a previous research. This technique is faster and easier to perform compared to other sampling techniques. The questionnaire was sent to Hungarian SMEs in an online format between May and September 2020 and 743 SMEs provided responses suitable for evaluation.

The questionnaire included open, closed, and Likert-scale questions on the following topics: general characteristics of the enterprise, employment characteristics, the impact of the crisis on the enterprise, managing the effects of the crisis, role of government measures, etc.

\section{FindiNGS AND DISCUSSION}

Figure 1 shows the distribution of enterprises participating in the survey, in a breakdown by size. According to the data depicted in the chart, the survey was mostly attended by small enterprises (602). An enterprise is considered small if the total number of its employees are less than 50 , and its total annual net sales do not exceed EUR 10 million. Figure 2 below shows the scope of activities of the surveyed enterprises.

The majority of respondents (283) were engaged in retail trade at the time of the survey, followed by tourism and hospitality (127), and financial services and consultancy (74). Agriculture (49) and the beauty industry (68) also contributed a relatively high number of respondents, while the lowest share of respondents was from mechanical engineering (19) and the construction industry (18).

To the general question about the impact of the coronavirus crisis on the company, most of the respondents $(85 \%)$ chose 


\section{Academic Workshop}

Figure 1: Enterprises participating in the survey, by size

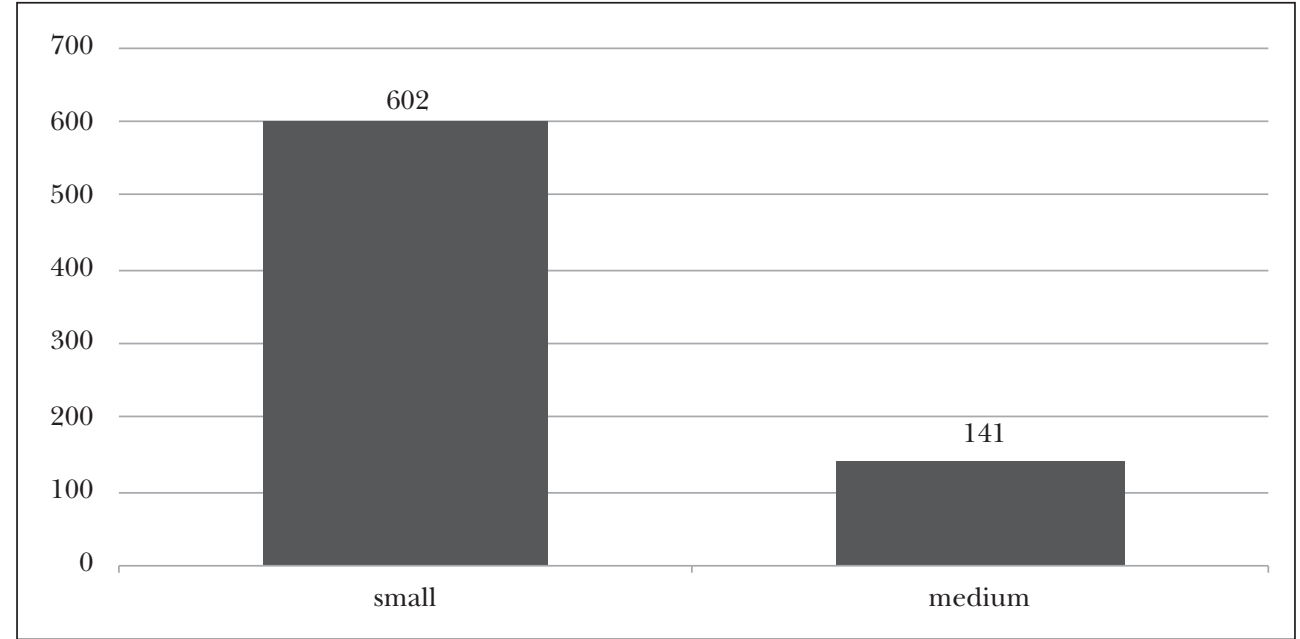

Source: Author's own elaboration (2020)

Figure 2: Activities of the enterprises participating in the survey

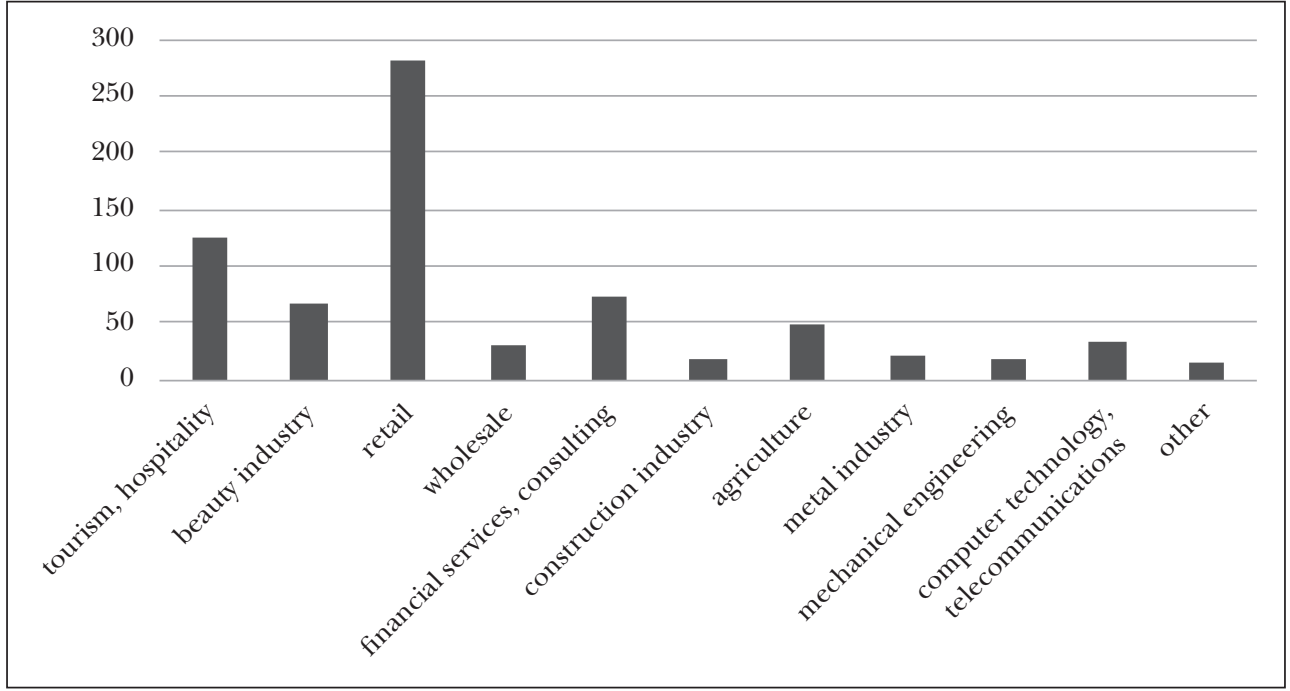

Source: Author's own elaboration (2020)

the option "adverse effect", followed by "no change" $(8 \%)$, while the option "favourable effect" was selected by only 3 per cent of the respondents, and 4 per cent could not answer the question at the time of the survey (Figure 3).
The above results confirm the findings of international research: the coronavirus will have a significant impact on the world economy (McKibbin and Fernando, 2020; Dennis, 2020). The COVID-19 pandemic is a global shock that disrupts supply and de- 


\section{Academic Workshop}

Figure 3: What impact has the coronavirus crisis had on your business? (\%)

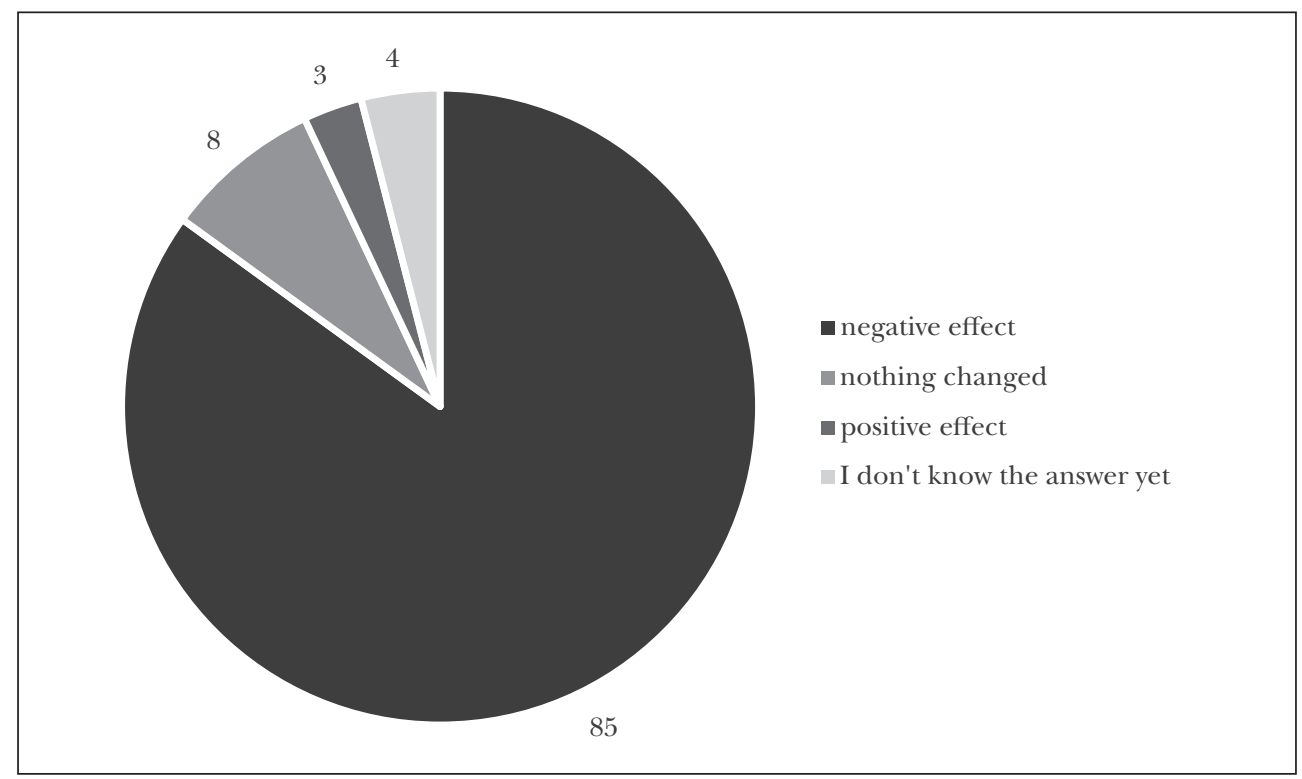

Source: Author's own elaboration (2020)

mand in the global economy. On the supply side, infections reduce labour supply and productivity, while enterprise closures and social isolation also cause supply disruptions (Veselovská, 2020). On the demand side, redundancies, the loss of income, and deteriorating economic outlooks are reducing household consumption and business investment (Zoidov and Medkov, 2020).

Based on the answers, it can be stated that SMEs were hit hardest by the coronavirus in Hungary, as it has affected their economic situation and daily operations. The most common adverse effects of the coronavirus on the enterprises were assessed on the basis of the survey.

According to Figure 4, the first of the adverse effects was the decline in demand for the product/service $(38 \%)$, followed by the emergence of financial problems (24\%), changes in the number of employees (13\%), problems with supply chains (12\%), drop in the price of the service/product provided $(9 \%)$, while the option "other" was picked by 4 per cent of the respondents.

The following Figure 5 shows the most important crisis management measures the surveyed companies had to take in order to mitigate the adverse effects of the crisis. The figures show that around 35 per cent of the surveyed companies were forced to take financial austerity measures, followed by work from home $(22 \%)$, the revision of contracts with partners $(16 \%)$, the dismissal of employees (12\%), the involvement of external capital (7\%), and finally, 4 per cent of respondents were forced to close down their businesses.

Governments have an important role to play in crisis management in all economies. In Hungary, without the help of the Hungarian government, enterprises would have found it difficult to survive the first wave of the coronavirus crisis. Among the most im- 


\section{Academic Workshop}

Figure 4: What adverse effects did your business perceive after the appearance of the coronavirus? (\%)

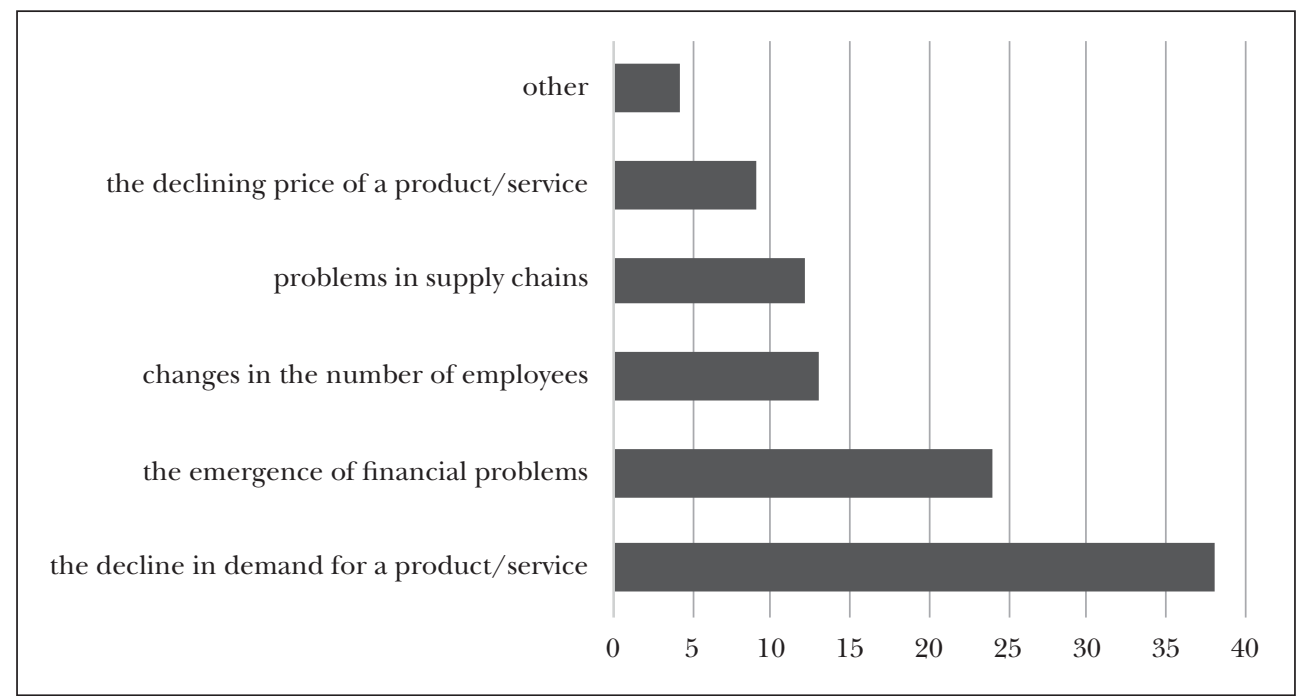

Source: Author's own elaboration (2020)

Figure 5: What crisis management solutions did you use to mitigate the effects of the coronavirus? (\%)

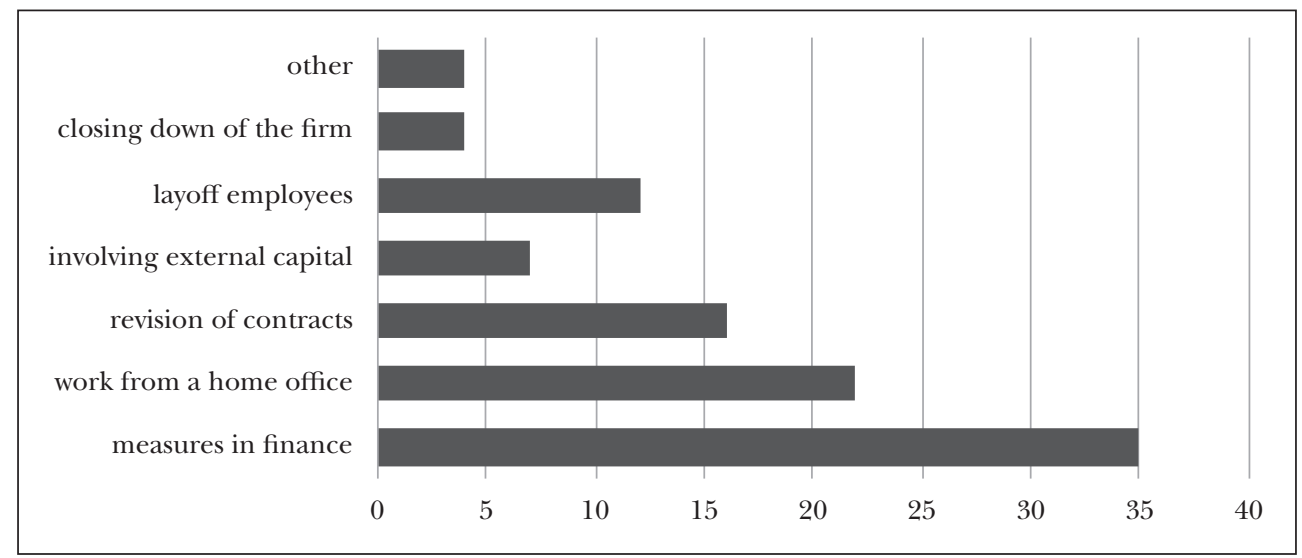

Source: Author's own elaboration (2020)

portant measures, support to job retention should be highlighted. Similarly to any other crisis, during the coronavirus crisis employee retention is jeopardised most. Many Hungarian SMEs could have got into trouble without the support of the government. These job retention benefits directly helped enterprises by taking over a signifi- cant part of workers' wages. Among the other economic measures, the reduction of taxes and incentives to direct economic activities should be emphasised, which all serve the maintenance of competitiveness for Hungarian businesses.

Hungarian businesses do everything within their power to avoid lay-offs, because 


\section{Academic Workshop}

they expect to be disadvantaged after the economic recovery if they cannot restart with a sufficient number of employees. Unfortunately, 3 per cent of enterprises surveyed went bankrupt because of the coronavirus. These results have been confirmed by several international publications (Zhili and Qingqing, 2020 and Dolbneva, 2020).

Government measures played an important role in all countries, and the economic protection action plans launched by the Government of Hungary were also of great assistance to SMEs. Based on the responses received, the surveyed enterprises generally had a favourable perception of the impact of government measures.

As multiple responses were allowed, it was made clear that many enterprises benefited from more than one options offered by the government to mitigate the effects of the coronavirus crisis.

According to Figure 6, the surveyed enterprises identified job protection programmes (541) and tax relief (245) and lending programmes (196) as the most effective governmental actions. The largest percent- age of respondents would like the Hungarian Government to help SMEs by reducing taxes or temporarily suspending taxes. Furthermore, employment-type subsidies are also important for SMEs that have not dismissed their employees. This is, moreover, in line with the statement by the world's major organisations that governments should temporarily take over part of the wage costs so that they can save jobs. Training grants (34) were marked as the least efficient, probably because they are less helpful to the SMEs surveyed in combating the coronavirus crisis than other action plans.

Based on the responses regarding the expected time of business recovery, the managers of the interviewed Hungarian SMEs think that 6 months to 1 year is the most likely $(61 \%)$ length of time required for recovery, followed by 3 to 6 months $(33 \%)$, and the most favourable version (within 3 months) was only chosen by 7 per cent of respondents (Figure 7). Based on these, it can be concluded that the post-crisis recovery is planned by the respondents in the medium to long term range.

Figure 6: What government measures has your business taken to alleviate the coronavirus crisis?

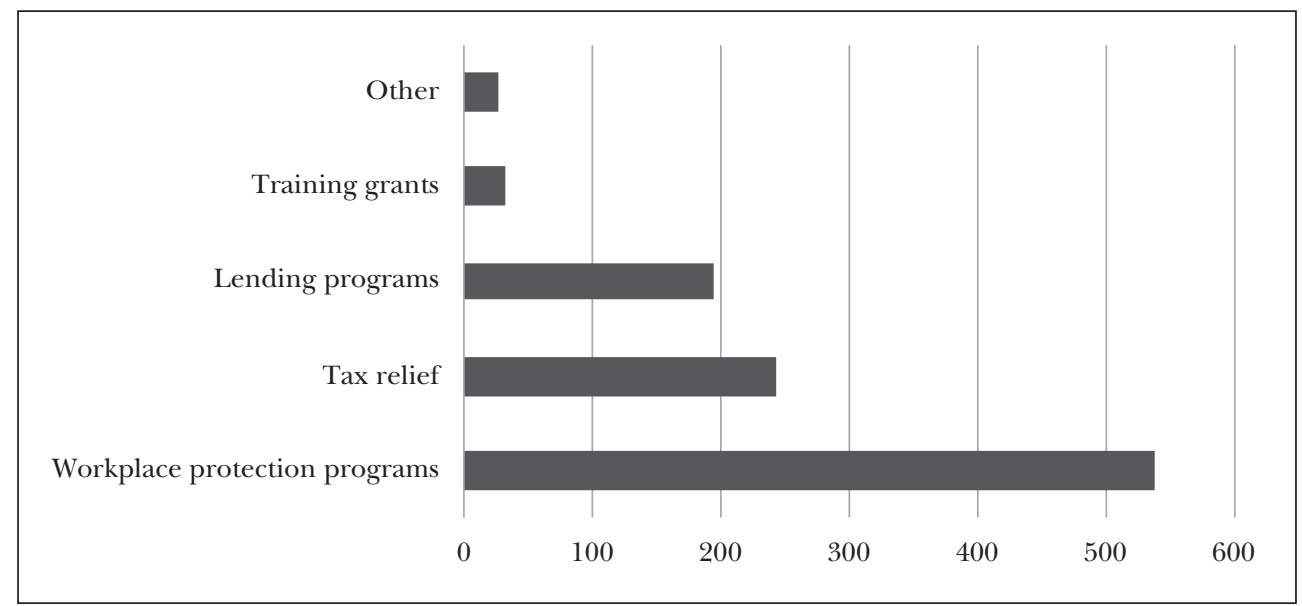

Source: Author's own elaboration (2020) 


\section{Academic Workshop}

Figure 7: Expected time of business recovery (\%)

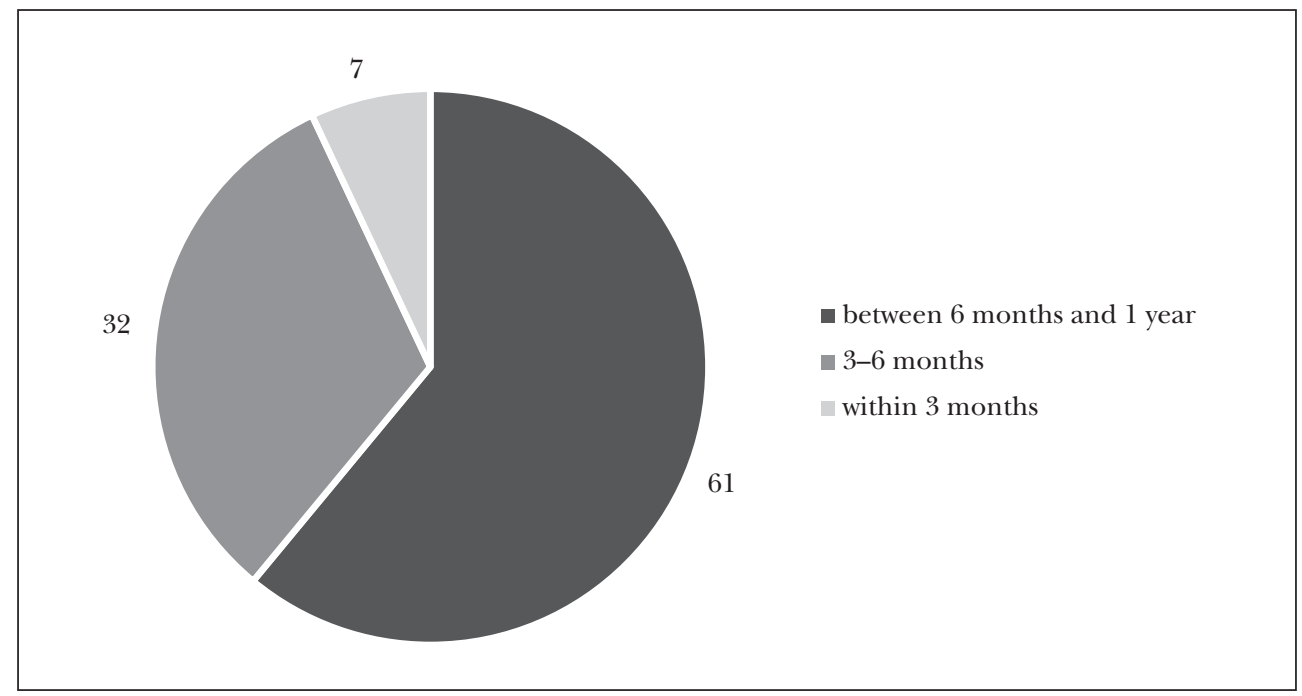

Source: Author's own elaboration (2020)

The study also proved that 2020 was a very difficult year for Hungarian SMEs. They faced a crisis they had never experienced before, the coronavirus crisis, which had a profound impact on their daily operations. Numerous enterprises were adversely affected, mainly manifest in financial problems and declining incomes, which in turn had an impact on employment. There is uncertainty about the future, and although the vaccine is already available, it is still not known when the economy will return to pre-crisis levels. According to forecasts, if the vaccine proves to be successful, rapid growth may start in the world economy, and this will also have a favourable impact on SMEs, which are critical factors in the functining of any national economy.

\section{Conclusions}

In addition to the number of ill and deceased citizens, recently the news also re- ported the fact that the coronavirus has had a significant effect on the economy. The key question for the future is how governments will be able to help enterprises keep this adverse economic impact to a minimum.

The research has shown that strengthening SMEs is essential for strengthening the economy, as they are the engines of any local economy and the largest employers in any country.

The results of the described research has also confirmed that a significant part of Hungarian SMEs face the adverse effects of the coronavirus. Note that there is a correlation between the coronavirus and the daily operation of Hungarian SMEs. Due to the coronavirus, working from home has also become widespread in Hungary, as the surveyed enterprises have switched from the traditional work schedule to flexible forms of employment.

According to the enterprises surveyed, government measures are important, and 


\section{Academic Workshop}

they would not be able to survive without them in the long run.

Thus, it can be said that supporting SMEs in crisis situations is a particularly important issue, but the economic strength of SMEs and the awareness of their managers, especially in financial, production, and management, need to be strengthened.

\section{REFERENCES}

Ahmad, T. and Hui, J. (2020): One Health Approach and Coronavirus Disease 2019. Human Vaccines E Immunotherapeutics, Vol. 16, No. 4, 931-932, https://doi.org/10.1080/21645515.2 020.1732168.

Baldwin, R., Di Mauro, W. B. (2020): Economics in the Time of COVID-19. A VoxEU.org Book, Centre for Economic Policy Research, London, https://voxeu.org/system/files/epublication/ COVID-19.pdf.

Barua, S. (2020): Understanding Coronanomics: The Economic Implications of the Coronavirus (COVID-19) Pandemic. http://dx.doi.org/10.2139/ssrn.3566477.

Dennis, M. J. (2020): The Impact of COVID-19 on the World Economy and Higher Education. Enrollment Management Report, Vol. 24, No. 9, 3-13, https://doi.org/10.1002/emt.30720.

Devins, D. and Kimbara, T. (1997): Competitive Advantage of SMEs in Manufacturing Industries. Local Economy: The Journal of the Local Economy Policy Unit, Vol. 12, No. 2, 133-145, https://doi. org/10.1080/02690949708726381.

Dolbneva, D. V. (2020): The Impact of COVID-19 on the World's Economies. The Problems of Economy, Vol. 1, No. 43, 20-26, https://doi. org/10.32983/2222-0712-2020-1-20-26.

Facebook/OECD/World Bank (2020): Global State of Small Business. https://dataforgood.fb.com/ global-state-of-smb/.

Fernandes, N. (2020): Economic Effects of Coronavirus Outbreak (COVID-19) on the World Economy. IESE Business School Working Paper, No. WP-1240-E.

Foo, J. and Witkowska, D. (2017): A Comparison of Global Financial Market Recovery after the 2008 Global Financial Crisis. Folia Oeconomica Stetinensia, Vol. 17, No. 1, 109-128, https://doi. org/10.1515/foli-2017-0009.
Gherghina, Ș. C.; Botezatu, M. A.; Hosszu, A. and Simionescu, L. N. (2020): Small and MediumSized Enterprises (SMEs): The Engine of Economic Growth through Investments and Innovation. Sustainability, Vol. 12, No. 1, 1-22, https:// doi.org/10.3390/su12010347.

Hite, L. M. and McDonald, K. S. (2020): Careers after COVID-19: Challenges and Changes. Human Resource Development International, Vol. 23, No. 4, 427-437, https:/ /doi.org/10.1080/13678868.20 20.1779576 .

Inozemtsev, V. (2020): How the Covid-19 Pandemic Impact the Economy. Current Digest of the Russian Press, Vol. 72, No. 7, 18-18, https://doi. org/10.21557/dsp.58004784.

KSH (2020a): Egy fốre jutó bruttó hazai termék (2000-) [Per capita GDP (since 2000)]. www.ksh.hu/ $\mathrm{docs} / \mathrm{hun} / \mathrm{xstadat} / \mathrm{xstadat}$ _eves/i_qpt014b. html.

KSH (2020b): A regisztrált gazdasági szervezetek száma gazdálkodási forma szerint, december 31 (2011-) [Number of registered business organisations in a breakdown of legal status as of 31 December (since 2011)]. www.ksh.hu/docs/hun/xstadat/ xstadat_eves/i_qvd009.html.

Lentner, Cs.; Vasa, L. and Hegedûs, Sz. (2020): The Assessment of Financial Risks of Municipally Owned Public Utility Companies in Hungary Between 2009 and 2018. Montenegrin Journal of Economics, Vol. 16, No. 4, 29-41, https://doi. org/10.14254/1800-5845/2020.16-4.3.

Lindley, D. (2020): Work Better from Home During the Coronavirus Quarantine. The Major Gifts Report, Vol. 22, No. 6, 1-10, https://doi. org/10.1002/mgr.31483.

Liu, W.; Yue, X.-G. and Tchounwou, P. B. (2020): Response to the COVID-19 Pandemic: The Chinese Experience and Implications for Other Countries. International Journal of Environmental Research and Public Health, Vol. 17, No, 7, 2-6, https://doi.org/10.3390/ijerph17072304.

Lund, S.; Ellingrud, K.; Hancock, B. and Manyika, J. (2020): COVID-19 and Jobs: Monitoring the US Impact on People and Places. McKinsey and Company.

Manjula Bai, H. (2020): The Socio-Economic Implications of the Coronavirus Pandemic (COVID-19). A Review. ComFin Research, Vol. 8, No. 4, 8-17, https://doi.org/10.34293/commerce.v8i4.3293. 


\section{Academic Workshop}

Martirosyan, O. (2020): Youth Employment and Unemployment under the Influence of the COVID-19 Pandemic. Vestnik Bashkir Institute of Social Technologies, Vol. 3, No. 48, 69-74, https:// doi.org/10.47598/2078-9025-2020-3-48-69-74.

McKibbin, W. and Fernando, R. (2020): The Global Macroeconomic Impacts of COVID-19: Seven Scenarios. Asian Economic Papers, 1-55, https:// doi.org/10.1162/asep_a_00796.

Shah, S. G. and Farrow, A. (2020): A Commentary on "World Health Organisation Declares Global Emergency: A Review of the 2019 Novel Coronavirus (COVID-19)". International Journal of Surgery, Vol. 76, 128-129, https://doi. org/10.1016/j.ijsu.2020.03.001.

Táu, N. and Cretoiu, R. I. (2014): The Vulnerability of SMES in the Economic Crisis. Annals of Spiru Haret University, Economic Series, Vol. 5, No. 2, https://doi.org/10.26458/1421.

Vasa, L. (2010): Experiences of the CEE Countries on Overcoming of the World Economic Crisis. In: Abishev, A. (ed.): 5th Annual International Scientific Forum "Ryskulov Readings". Ekonomika Baspasy, Almaty Kazakhstan, 37-52.
Vasa, L. and Mendelényi, D. (2010): Leadership Principles at a Regional Company of A Multinational Corporation. In: Global Management Conference „Second Annual Conference on Globalisation, Sustainability and Development". Conference paper, 276-293.

Veselovská, L. (2020): Supply Chain Disruptions in the Context of early Stages of the Global COVID-19 Outbreak. Problems and Perspectives in Management, Vol. 18, No. 2, 490-500, https:// doi.org/10.21511/ppm.18(2).2020.40.

Zhili, W. and Qingqing, Y. (2020). The Impact of Economy, Policy, and Medical Care on the COVID-19 Pandemic. Scholars Journal of Physics, Mathematics and Statistics, Vol. 7, No. 9, 188-191, https://doi.org/10.36347/sjpms.2020.v07i09. 001.

Zoidov, K. K. and Medkov, A. A. (2020): Impact of the COVID-19 Coronavirus Pandemic and Its Control Measures on the Functioning of Trade Routes. Market Economy Problems, No. 2, 48-60, https://doi.org/10.33051/2500-2325-2020-248-60. 